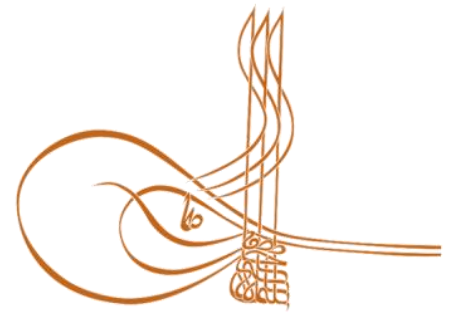

www.turkishstudies.net/economy
Turkish Studies - Economics, Finance, Politics

eISSN: 2667-5625

Research Article / Araştırma Makalesi

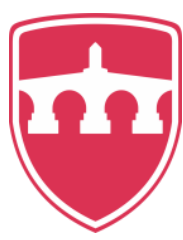

INTERNATIONAL BALKAN

UNIVERSITY

Sponsored by IBU

\title{
1915 Olaylarına Dair Türk-Ermeni Uyuşmazlığı ıe Sivil Toplum Girişimlerinin Uyuşmazlık Çözümündeki Başarısının Gerçekçi Çatışma Kuramı Açısından Analizi
}

\author{
The Analysis of Turkish-Armenian Conflict Related to the 1915 Events And The Success of Civil \\ Society Initiatives in the Conflict Resolution Through Realistic Conflict Theory
}

\author{
Betül Özyılmaz Kiraz*
}

\begin{abstract}
The enactment of the Relocation and Resolution Law on April 24, 1915, which corresponds to the disintegration period of the Ottoman Empire, and the events that occured during the relocation of the Armenians according to the law and that is known as the 1915 Events have been an issue of conflict between Turkey and Armenia. This conflict does not only affect bilateral relations between Turkey and Armenia, but it also has impact on the international relations of Turkey in the general sense. Because of this reason, the conlict related to the 1915 Events constitute a must-be-solved problem for Turkish foreign policy. Based on this recognition, there have been various civil society initiatives and efforts in order to solve the problem; however, currently it is impossible to say that these initiatives have ended up with success. The aim of this article is to answer to the questions that why these initiatives are not enough to solve the problem and that what can be done for the future success of such initiatives. The theoretical framework of the article is constructed on realistic conflict theory. According to realistic conflict theory, intergroup conflict is the result of incompatible group interests and goals. Competition between groups on limited resources leads to intergroup conflict. In addition to pointing out the roots of intergroup conflict, realistic conflict theory also reveals the effective means of conflict resolution. Accordingly, cooperation to achieve higher goals has the potential to reduce intergroup disagreement over time and create positive relations between members of collaborating groups. At the end of the analysis based on this theoretical framework, it is concluded that the main reason behind Turkish-Armenian conflict related to the 1915 Events is conflicting aims and interests of two sides regarding how the 1915 Events must be described. In this situation, the success of the one side in reaching its interest means the failure of the other side. In addition to this, it is concluded in the study that introduction of the superordinate goals is necessary but not sufficient for the success of civil society initiatives. It is argued it the study that in addition to the introduction of the superordinate golas, government support is a precondition for the success. The government support has key importance in the success of the civil socity initiatives in such a sensitive issue. In the absence of this support, the civil society initiatives are faced with the problem of legitimacy and foundation. It is for this reason that the civil society initiatives regarding this conflict should be supported continiously; that rather than political openings introduced from
\end{abstract}

\footnotetext{
* Arş. Gör., Ankara Hacı Bayram Veli Üniversitesi, İktisadi ve İdari Bilimler Fakültesi Uluslararası İlişkiler Bölümü Res. Asst., Ankara Hacı Bayram Veli University, Faculty of Economics And Administrative Sciences ORCID 0000-0002-1513-3290 betulozyilmaz@yahoo.com Cite as/ Atıf: Özyılmaz Kiraz, B. (2020). 1915 olaylarına dair Türk-Ermeni uyuşmazlığı ve sivil toplum girişimlerinin uyuşmazlık çözümündeki başarısının gerçekçi çatışma kuramı açısından analizi, Turkish Studies - Economy, 15(1), 463-479. https://dx.doi.org/10.29228/TurkishStudies.40411

Received/Geliş: 03 January/Ocak 2020

Checked by plagiarism software

Accepted/Kabul: 25 March/Mart 2020

Published/Yayın: 30 March/Mart 2020

Copyright (C) INTAC LTD, Turkey

CC BY-NC 4.0
} 
time to time there should be a process which is less incentive in terms of content but continious in terms of duration.

Structured Abstract: The enactment of the Relocation and Resolution Law on April 24, 1915, which corresponds to the disintegration period of the Ottoman Empire, and the events that occured during the relocation of the Armenians according to the law and that is known as the 1915 Events have been an issue of conflict between Turkey and Armenia. This conflict does not only affect bilateral relations between Turkey and Armenia, but it also has impact on the international relations of Turkey in the general sense. Because of this reason, the conlict related to the 1915 Events constitute a must-be-solved problem for Turkish foreign policy. Based on this recognition, there have been various civil society initiatives and efforts in order to solve the problem; however, currently it is impossible to say that these initiatives have ended up with success. The aim of this article is to answer to the questions that why these initiatives are not enough to solve the problem and that what can be done for the future success of such initiatives.

While searching for answers to these questions, the theoretical framework of the article is constructed on realistic conflict theory in the field of social psychology. The selection of a social psychological approach and a theory of intergroup relations in particular in an international relations article is related to the assumption that international relations is a form of intergroup relations. In its simplest form, intergroup relations refer to the relations between in-group and out-group members within the framework of their group identities. In this sense, both the conflict between Turkey and Armenia based on the 1915 Events and a discussion between a Turk and an Armenian based on their national identities are in the context of the intergroup relations. Likewise, the interaction of a non-governmental organization from Turkey and a nongovernmental organization from Armenia, or a joint civil society initiative composed of Turks and Armenians representing their Turkish and Armenian identities is an intergroup relation. For this reason, in this study the civil society initiatives introduced to contribute to the resolution of Turkish-Armenian conflict are dealt with through the theoris of intergroup relations.

Realistic conflict theory is essentially a social psychology theory that explains intergroup behaviour in economic terms. Realistic conflict thoery is based on three basic assumptions. First, people are selfih and strive to maximize their earnings. Second, intergroup conflict is the result of incompatible group interests and goals. Competition between groups on limited resources leads to intergroup conflict. Finally, the social psychological aspects of intergroup behavior are not a determinant of the incompability of group interest, but rather determined by them. In particular, the second and third assumptions provide important clues about the factors that shape intergroup attitudes and behaviours in general and the causes of intergroup conflict in particular. In addition to pointing out the roots of intergroup conflict, realistic conflict theory also reveals the effective means of conflict resolution. Accordingly, cooperation to achieve higher goals has the potential to reduce intergroup disagreement over time and create positive relations between members of collaborating groups.

At the end of the analysis based on this theoretical framework, it is concluded that the main reason behind the Turkish-Armenian conflict related to the 1915 Events is conflicting aims and interests of two sides regarding how the 1915 Events must be described. In this situation, the success of the one side in reaching its interest means the failure of the other side. In addition to this, it is concluded in the study that introduction of the superordinate goals is necessary but not sufficient for the success of civil society initiatives. It is argued in the study that arguments of realistic conflict thoery need to be supplemented by Allport's social contact perspective. According to Allport, there are four conditions for intergroup contact to be successful: (1) equal status of group members; (2) superordinate goals; (3) intergroup cooperation; (4) support of the third parties such as institutions and laws. It is revealed in this study that even if the interacting group members are equal in status; there are superodinate goals and subsequent intergroup cooperation; civil society initiatives regarding Turkish-Armenian conflict based on 1915 Events have not brought resolution yet due to the fluctiations in government support. In addition to the introduction of the superordinate golas, government support is a precondition for the success. The government support has key importance in the success of the civil socity initiatives in such a sensitive issue. In the absence of this support, the civil society initiatives are faced with the problem of legitimacy and foundation. It is for this reason that the civil society initiatives regarding this conflict should be supported continiously; that rather than political openings introduced from

Turkish Studies - Economy, 15(1) 
time to time there should be a process which is less incentive in terms of content but continious in terms of duration.

Keywords: 1915 Events, Turkish-Armenian Conflict, Civil Society, Realistic Conflict Theory

Öz: Osmanlı Devleti'nin dağılma dönemine tekabül eden 24 Nisan 1915 tarihinde çıkarılan Sevk ve İskân Kanunu'nun çıkarılması ve takiben savaş bölgesindeki Ermenilerin göç ettirilmesi sürecinde yaşanan ve 1915 Olayları olarak bilinen olaylar günümüzde Türkiye ile Ermenistan arasında bir uyuşmazlık konusudur. Bu uyuşmazık, yalnızca Türkiye ve Ermenistan'ın ikili ilişkilerini değil, Türkiye'nin uluslararası ilişkilerini genel anlamda etkilemesi bakımından Türk dış politikasında çözülmesi gereken bir sorun teşkil etmektedir. Durumun farkındalığından hareketle, sivil toplum düzeyinde birçok girişim ve çaba ortaya konulmuşsa da 2020 yılı itibarıyla bu girişimlerin ve çabalarının başarıyla sonuçlandığını ifade etmek mümkün değildir. $\mathrm{Bu}$ çalışmanın amacı, günümüze kadarki çabaların neden uyuşmazlığı çözmekte yeterli olmadığı ve bundan sonra nasıl bir yol izlenmesi gerektiği sorularına cevap bulmaktır. Çalışmanın kuramsal çerçevesi gerçekçi çatı̧̧a kuramı inşa edilmiştir. Gerçekçi çatışma kuramına göre gruplararası uyuşmazlığın temelinde grupların farklı ve örtüşmeyen çıkarlara ve hedeflere sahip olması yatmaktadır. Bir grubun çıkarını elde etmesinin diğer grubun başarısızlı̆̆ olmaktadır. Gruplararası uyuşmazlıkların nedenini bu şekilde açıklayan gerçekçi çatışma kuramı, aynı zamanda uyuşmazlık çözümünün etkili bir aracı olarak üst bir hedefin tanınmasına işaret etmektedir. Buna göre, üst hedeflere ulaşılması için yapılan işbirliği zaman içerisinde gruplararası uyuşmazlığı azaltma ve işbirliği yapan grupların üyeleri arasında olumlu ilişkiler yaratma potansiyeline sahiptir. Bu kuramsal temele dayanarak yapılan analizler doğrultusunda, 1915 Olayları'na bağlı olarak yaşanan uyuşmazlığın temelinde, olayların nasıl tanımlanması gerektĭği noktasında Türkiye ve Ermenistan'ın farklı çıkarlarının ve hedeflerinin olması yattı̆̆ diğer grubun başarısızlığı anlamına gelmektedir. Buna ek olarak, çalışmada, sivil toplum girişimlerinin başarılı olması için gruplararası işbirliğini gerektirecek üst hedeflerin tanımlanmasının gerekli olduğu, ancak yeterli olmadığı sonucuna varılmıştır. Çalışmada, üst hedeflerin sunulmasına ek olarak söz konusu girişimlerin hükümetler tarafından desteklenmesi gerektiği savunulmaktadır. Hükümet desteği, 1915 Olayları gibi hassas bir konudaki sivil toplum girişimlerinin başarıya ulaşabilmesi açısından kilit öneme sahiptir. Zira bu destek söz konusu olmadığında sivil toplum girişimleri, meşruiyet ve fon bulma sorunuyla karşı karşıya kalmaktadır. Bu nedenle, sivil toplum girişimleri sürekli olarak desteklenmeli; zaman zaman gerçekleşen siyasi açılımlardan ziyade açılımlara göre içerik olarak daha az yoğun ama sürekli açık bir süreç olmalıdır.

Anahtar Kelimeler: 1915 Olayları, Türk-Ermeni Uyuşmazlığı, Sivil Toplum, Gerçekçi Çatışma Kuramı

\section{Giriş}

Osmanlı Devleti'nin dağılma dönemine tekabül eden 24 Nisan 1915 tarihinde Sevk ve İskân Kanunu'nun çıkarılması ve onu takiben savaş bölgesindeki Ermenilerin göç ettirilmesi sürecinde yaşanan ve "1915 Olayları" olarak bilinen olaylar, günümüzde Türkiye ile Ermenistan arasında bir uyuşmazlık konusudur. Ermeniler, söz konusu süreçteki yaşadıkları acıları ve kayıpları soykırım olarak tanımlarken, Türkiye açısından 24 Nisan kararlarını ve Ermeni tehcirini bir soykırım olarak tanımlamak mümkün değildir. 1915 Olayları'na dair bu görüş ayrılıklarından kaynaklanan uyuşmazlık, yalnızca Türkiye ve Ermenistan'ın ikili ilişkilerini etkilememekte; Ermenistan'ın olayları diğer ülkelere de bir soykırım olarak tanıtma politikasının sonucu olarak Türkiye'nin uluslararası ilişkilerini genel anlamda etkilemektedir. 24 Nisan tarihini "Ermeni Soykırım Günü" olarak kabul eden Ermenistan, diğer ülkelere de bu şekilde kabul ettirmeye çalışmaktadır. Ermeni lobileri, 1915 Olayları'nı soykırım olarak kabul eden ve bunu inkâr edenlerin cezalandırılmasını öngören yasa tasarılarını çeşitli ülkelerin parlamentolarında kabul ettirmek için çalışmaktadır. Avrupa Birliği (AB), Ermenistan'la yaşanan bu uyuşmazlığı Türkiye'nin AB üyeliği yolunda bir engel olarak sunmakta ve uyuşmazlığın çözümünü adeta üyeliğin bir önkoşul olarak addetmektedir. 
Söz konusu yasa tasarılarının kabul edilmesinin Türkiye açısından bir bağlayıcılığı bulunmamaktadır. Öte yandan Türkiye'nin Ermenistan'la olan uyuşmazlığının, AB'nin Türkiye'nin üyeliğini engellemek için öne sürdügü birçok bahaneden bir tanesi olduğunu açıkça görmek zor değildir. Ancak nihayetinde 1915 Olayları'na dair yaşanan uyuşmazlık, Türkiye'nin uluslararası ilişkilerini olumsuz etkileyebilmekte; üçüncü taraflarla ilişkilerinde sınırlayıcı bir rol oynamakta ve bu sorunun varlığı Türkiye'nin karşısına bir koz olarak çıkabilmektedir. Türkiye'nin yakın müttefiki ABD'nin, Senatosunda 1915 Olayları'nı soykırım olarak tanıyan bir karar tasarısının kabul edilmesi, Türkiye'nin Suriye'ye yönelik askeri operasyonları ve bunun ABD'de yarattığı rahatsızlık göz önünde bulundurulduğunda, söz konusu uyuşmazlığın Türkiye'ye karşı nasıl bir yaptırım ya da tehdit aracına dönüşebildiğinin en güncel örneğidir. Bu haliyle, 1915 Olayları konusunda yaşanan uyuşmazlık, Türk dış politikasında çözülmesi gereken bir sorun teşkil etmektedir.

Durumun farkındalığından hareketle, 1990'lı y1llardan günümüze kadar sivil toplum düzeyinde birçok girişim ve çaba ortaya konulmuştur. Ancak 2020 yılının baş1 itibarıyla bu girişimlerin ve çabaların, 1915 Olayları'na dair Türk-Ermeni uyuşmazlığına çözüm getirmekte başarılı olduğunu ifade etmek mümkün değildir. Bu çalışmanın temel amacı, bugüne kadarki sivil toplum girişimlerinin neden uyuşmazlıkta çözmekte yeterli olmadığı ve bundan sonra nasıl bir yol izlenmesi gerektiği sorularına cevap bulmaktır. Bu sorulara cevap ararken çalışmanın kuramsal çerçevesi, sosyal psikoloji alanına ait gerçekçi çatışma kuramı üzerine inşa edilmiştir. Konusu uluslararası ilişkiler olan bir çalışmada, sosyal psikoloji ve özel olarak da bir gruplararası ilişkiler kuramının seçilmesi, uluslar arasında cereyan eden ilişkilerin esasında bir tür gruplararası ilişki olduğu varsayımından kaynaklanmaktadır.

Gruplararası ilişkiler, en basit haliyle, iç-grup üyeleri ile dış-grup üyelerinin grup kimlikleri çerçevesinde kurdukları ilişkileri tanımlamaktadır. Bu tanıma göre, gruplararası ilişkilerden söz etmek için iki ya da daha fazla grubun bir bütün olarak etkileşimde bulunmaları şart değildir. Bir grubun üyelerinin, başka bir grubun üyeleriyle münferit olarak, ancak grup kimlikleri bağlamında kurduğu etkileşim de gruplararası ilişkilerin kapsamına girmektedir. Bu durumda, Türkiye ile Ermenistan arasında 1915 Olayları konusunda yaşanan uyuşmazlığın gruplararası ilişkiler kapsamında olması gibi bir Türk ve bir Ermeni'nin ulusal kimlikleri bağlamında yaşadıkları bir tartışma da gruplararası bir ilişkidir. Benzer şekilde, Türkiye'de bulunan bir sivil toplum kuruluşu ile Ermenistan'da bulunan bir sivil toplum kuruluşunun etkileşimi ya da Türk ve Ermenilerin, Türk ve Ermeni kimliklerini temsilen katıldıkları ortak bir sivil toplum girişimi de gruplararası ilişkidir. Bu nedenle, bu çalışmada 1915 Olayları'na dair uyuşmazlığın çözümüne katkıda bulunmak üzere ortaya konulan sivil toplum girişimleri, gruplararası ilişkiler kuramlarından faydalanılarak ele alınmaktadır.

Çalışmanın kuramsal çerçevesinin açıklanmasına ayrılan ilk kısmında, gerçekçi çatışma kuramın ortaya çıkışı ve temel argümanları açıklanmaktadır. İkinci bölümde, 1915 Olayları'na dair uyuşmazlığın nedeni, sunulan kuramsal çerçeveye bağlı kalınarak analiz edilmektedir. Üçüncü bölümde, çözüm konusundaki girişimler incelenirken, son kısımda ise bu girişimlerin henüz çözümü getirememesinin sebepleri yine gerçekçi çatışma kuramı perspektifinden değerlendirilmekte; tespit edilen eksiklikler göz önünde bulundurularak sorunun çözümüne dair öneriler sunulmaktadır.

\section{Gerçekçi Çatışma Kuramı: Ortaya Çıkışı ve İçeriği}

Muzafer Sherif'in ortaya koyduğu gerçekçi çatışma kuramı, özü itibarıyla gruplararası davranışı ekonomik yönden açıklayan bir sosyal psikoloji kuramıdır. Gerçekçi çatışma kuramı, üç temel varsayıma dayanmaktadır. Birincisi, insanlar bencildir ve kendi kazançlarını azami dereceye çıkarmak için çaba göstermektedirler. İkincisi, gruplararası çatışma, birbiriyle bağdaşmayan grup çıkarlarının ve hedeflerinin bir sonucudur. Gruplar arasında sınırlı kaynaklar üzerine olan rekabet, gruplararası çatışmaya sebep olmaktadır (LeVine ve Campbell, 1972: 72). Son olarak, gruplararas1 davranışın sosyal psikolojik yönleri, grup çıarlarının bağdaşmasının ya da bağdaşmamasının bir 
belirleyicisi değillerdir, aksine onlar tarafindan belirlenmektedirler (Taylor ve Moghaddam, 1994: 35). Özellikle ikinci ve üçüncü varsayım, genel olarak gruplararası tutum ve davranışları şekillendiren unsurlara ve özel olarak da gruplararası çatışmanın sebeplerine dair önemli ipuçları sunmaktadır.

Sherife göre, iki grubun üyelerinin birbirlerine yönelik karş1lklı tutumlarının şekillenmesinde sınırlayıcı belirleyici, gruplar arasındaki işlevsel ilişkilerin niteliği olmaktadır. Söz konusu gruplar bir hedefe ya da hayati bir ödüle ulaşmak için rekabet halinde olabilirler ki bu durumda bir grubun başarısı mutlaka diğerinin başarısızlığı anlamına gelmektedir. Bir grubun, başka bir grup üzerinde, onları yönetme, kontrol etme ya da onlardan kendi yararına istifade etme; onların gerçek veya üstlenilmiş haklarını ya da mülklerini devralma gibi birtakım iddiaları bulunabilir. Öte yandan, grupların birbirlerini tamamlayan hedefleri olabilir ve dolayısıyla her biri diğerinin başarısını engellemeden ve hatta onun başarıya ulaşmasına yardımcı olarak amacına ulaşabilir. (Sherif vd., 1988: 200).

İki ya da daha fazla grup, hedeflerine ulaşmaları açısından birbirlerine bağımlıysa; hedefleri birbirlerinin hedefleri ile çatışmıyorsa ya da birbirini tamamlayan hedeflerse, bu grupların karşılıklı tutum ve davranışlarının işbirliğine dayalı ve olumlu olması beklenmektedir. Ancak farklı gruplar, aynı hedefe ulaşmak istediklerinde, aralarındaki bağımlılık uyumsuz bir hale gelmekte ve rekabet yükselmektedir (Figueiredo vd., 2014: 10). Bu tür bir rekabette gruplardan birinin hedefine ulaşmakta başarılı olması, diğer grubun başarısızlı̆̆ı anlamına gelmektedir. Bu şekildeki çıkar çatışmaları dış gruba karşı negatif tepkileri besleyen iç-grup normlarının gelişmesine ve bu normlara karşı çıkan iç-grup üyelerinin cezalandırılmasına ve dışlanmasına yol açmaktadır (Schofield, 2010: 681). Kısacas1, gruplar, birbirleriyle bağdaşmayan hedeflerin bulunduğu davranış ortamlarında etkileşime girdiklerinde, bu hedefleri elde etmek için birbirleriyle rekabet etmektedirler ve bu durum zamanla gruplar arasında düşmanlığa yol açmaktadır (Arkonaç, 2001: $324)$.

Grupların sınırlı kaynaklara erişmek için rekabet halinde olduklarını ve gruplararası ilişkilerde çatışmaların temel sebebinin bu rekabet olduğunu savunan Sherif, bu görüşleri test etmek üzere çalışma arkadaşları ile birlikte, "Hırsızlar Mağarası Deneyi/The Robbers Cave Experiment" olarak bilinen bir dizi deney yapmıştır (Hogg ve Vaughan, 2005: 398). Deneyler, 12 yaşlarında, birbirini tanımayan, orta sosyo-ekonomik sınıftan ve Protestan ailelerden gelen, aynı eğitim düzeyinde olan, sağlıklı 22 erkek çocuğun katılımıyla gerçekleştirilmiştir. Yani denekler yaş, cinsiyet, sosyo-ekonomik durum, dini değerler ve eğitim açısından denk ve daha önceden hiç irtibat kurmamıș bireylerden oluşmuștur. Şüphesiz ki Sherif ve diğer araștırmacıların buradaki amacı, kişisel özellikler ve mevcut kişisel ilişkiler gibi unsurları sabit tutarak, bunların deney sonuçları üzerindeki olası etkilerini ortadan kaldırmaktır. Örneğin seçilen çocuklardan bazıları farklı bir dini gruba mensup olsaydı; yaş olarak farklı bir yaş grubunda olsaydı; bazı çocuklar kız bazıları erkek olsaydı ya da bazıları birbirlerini önceden tanıyor olsaydı bu durum, benzer kategoride olan çocukların birbirlerine karşı bir sempati beslemesine yol açmak suretiyle deneyin seyrini ve sonucu etkileyebilirdi. Bu nedenle deneyde, temel kişisel özellikler açısından benzer ve daha önce birbirini tanımayan bir grup çocuk seçildiği düşünülmektedir.

Deneylerin birinci aşamasında, çocuklar bir kamp ortamında bir araya getirilmiş ve kendilerine arkadaşlık kurmalarına olanak tanıyacak şekilde bazı kamp görevleri verilmiştir. İkinci aşamada, spor aktiviteleri ve diğer birtakım gruplararası yarışmalarda yer almak üzere iki grup bir araya getirilmişlerdir. Bu aşamada, rekabet ve gruplararası düşmanlığın ortaya çıktığı ve bu durumun yarışmalar dışında da kendisini göstermeye devam ettiği gözlemlenmiştir. Rekabet içeren bu aşama, önyargıların ayrımcılığa dönüştüğü nokta olmuştur. Grupların birbirleriyle bağdaşmayan hedeflerinin gruplararası rekabeti doğurduğu ve buna bağlı olarak, dış-gruplara karşı ayrımc1 davranışlar ortaya çıktığı görülmüştür. Etnik merkezci tutumlar ve davranışlar güçlenmiş ve gruplararası saldırganlık ve iç-grup dayanışması artmıştır. Görüldüğü üzere, birinci aşamada ortaya 
konan problem durumları, bir grup içindeki tüm üyeler açısından anlık cazibesi olan hedefler içermiştir ve bu hedeflere ulaşılması, grup üyelerinin uyumlu bir şekilde faaliyet göstermelerini ya da eşgüdümlü işbölümünü gerektirirken, ikinci aşamada sunulan problem durumları, bir grup tarafından elde edilmesinin, zorunlu olarak diğer grubun başarısızlığ oluşmuştur. Bu ortamda, gruplararası çatışma ortaya çıkmıştır (Sherif vd., 1988: 205).

Deneyin üçüncü aşamasında ise, iki gruba üst hedefler verilmiştir. Üst hedefler, her iki grubun da ulaşmak istedikleri ancak kendi başlarına ulaşmaları mümkün olmayan hedefleri tanımlamaktadır. Dolayısıyla, bu aşamada gruplar, işbirliği içerisinde birlikte çalışmak durumundadırlar. Örneğin gruplara, her iki tarafın da izlemeyi çok istediği bir filmi getiren aracın çamura saplandığı ve çamurdan çıkması için herkesin yardımına ihtiyaç duyulduğu söylenmiştir (Hogg ve Vaughan, 2005: 399). Bu aşamada, gruplararasındaki hâkim uyuşmazlığın azaldığ1 görülmüştür. Karşılıklı işbirliğine ve yardıma dayalı gruplararası eylemlerde, dostane araç değiş tokuşunda, alternatif sorumluluklar için standart prosedürlerin geliştirilmesinde ve sorunlarla baş edilmesinde çatışma ve düşmanlığın azaltıldığ 1 gözlenmiştir. Dış-gruba dair olumlu fikirler geliştirilmiş, böylece iç-grubun ve dış-grubun derecelendirmeleri artık bir dizi karşıllaştırılmış kutuplaşma oluşturmaktan çıkmıştır. Araştırmacılar, bu aşamada davranışlardaki ve gruplar arasındaki etkileşimin şeklinde meydana gelen değişimi çarpıcı olarak tanımlamaktadır (Sherif vd., 1988: 211).

Sherif, üçüncü aşamanın başlangıcında aslında gruplararası ilişkiler çalışmalarında şemsiye bir terim haline gelen "temas" terimini açıklığa kavuşturma amacını taşıdığını açıklamıştır (Sherif vd., 1988: 210). Sherif'in temas kavramına bu şekilde atıfta bulunması ve onu açıklığa kavuşturmak istemesi, deneyin yapıldığı 1950'li yıllarda sosyal psikoloji literatüründe hâkim olan sosyal temas konulu tartışmalardan ileri gelmektedir. Sosyal temas hipotezi, farklı gruplardan bireyler arasında etkileşimsizlik ve ayrışmanın önyargıları güçlendirdiği gibi, birbirine karşı olumsuz algılar besleyen grup üyeleri arasında sosyal temas sağlanmasının da önyargıları azaltabileceği varsayımına dayanmaktadır. Bu varsayım, bahsi geçen tartışmanın bir ucunu oluştururken diğer uçta, sosyal temasın daima olumlu tutum değişiklikleriyle sonuçlanmadığını, aksine bazı durumlarda önyargıyı ve grupların birbirlerine karşı düşmanca tutumlarını gösteren araştırmalar bulunmaktadır (Gürkaynak, 2018: 257).

Sherifin dem vurduğu 1950'li yılların bu entelektüel ikliminde Allport, sosyal temas ile ilgili kuramını ortaya koymuştur. "Önyargının Doğas1/The Nature of Prejudice" eserinde sosyal temas konusundaki görüş ayrılıklarına değinen Allport nihayetinde, sosyal temasın önyargıyı azaltabileceği, ancak bunun dört tane pozitif unsurun sağlanması durumunda gerçekleşebileceği sonucuna varmıştır. Bu unsurlar (1) grup üyelerinin eşit statüde olması; (2) ortak hedeflerin varlığı; (3) gruplararası işbirliği; (4) kurumlar ya da yasalar gibi üçüncü tarafların desteğidir (Pettigrew ve Tropp, 2005: 264). Ancak Sherif'in deneyinin son aşamasına bakıldığında, Allport'un tanımladığı bu unsurlardan üçüncü tarafların desteği deneyde görülmektedir. Bunun bilinçli bir tercih olduğu anlaşılmaktadır. Nitekim çalışma ekibi, deneyde, üst hedeflerin takdim edildiği şartlar ve koşullar, gözlemciler tarafından özenle hazırlandığını, ancak sahneyi kurmanın ötesinde, izlenecek yöntemler, çözüm için gerekli olan tartışma, yapılacak ve uygulanacak planlar tamamen gruplara bırakılmıştır. Üst hedefleri ile karşı karşıya kalan gruplar gerektiğinde tartışmaya devam etmiş, her iki grubun da becerikli üyelerinin tavsiye ve önerilerini dinlemiş, kararlar almış ve hatta hedefe daha etkili bir şekilde ulaşılacağı düşünüldüğünde tartışmaları, kararları ve eylemleri eş zamanlı olarak birleştirmişlerdir. (Sherif vd., 1988: 211-212). Dolayısıyla, gruplararası temas sürecinde gruplar kendi hallerine bırakılmış; süreci destekleyen üçüncü tarafların varlığı söz konusu olmaksızın işbirliklerini sürdürebilmişlerdir.

Sherif, deneysel girişiminin son aşamasını kast ederek, gruplararası uyuşmazlığın azaltılmasına yönelik çeşitli önlemler denenebileceğine değinmekte ve neden tüm olası önlemler içinden üst hedeflerin devreye sokulmasının tercih edildiğini açıklamaktadır. Örneğin gruplararası 
çatışmanın azaltılması için olası bir önlem olarak, iki grup için de "ortak bir düşman" sunulabilirdi. Ortak bir düşmanın varlığıyla karşı karşıya gelen grupların, ortak tehdidi ortadan kaldırmak için birlik olmaları beklenirdi. Ancak araştırmacılar bunu tercih etmemiştir, çünkü bu tür bir müdahale, daha büyük ölçekte gruplararası çatışmaların ortaya çıkması anlamına gelecekti. Başka bir olası yaklaşım, hâkim grup kalıpyargılarını düzeltmek üzere tasarlanmış özel bilgilerin yayılması olabilirdi. $\mathrm{Bu}$ önlem, bir grubun temel kaygıları ile ilgili olmayan soyut bilgilerin, tutum değişiminde göreceli olarak etkisiz olduğunu gösteren çok sayıda araştırmanın bulunması nedeniyle ciddi olarak düşünülmemiştir. Zira Sherif'e göre, dış-grupla olan rekabet ve uyuşmazlık süreci boyunca belirginleşen kalıpyargılar, grup üyelerine sunulan bilgi parçalarından daha gerçektir. Gruplararası uyuşmazlığı azaltmak için en etkili önlem olarak seçilen alternatif, deneyden önce belirtilen varsayımlara paralel olarak, bir dizi üst hedefin ortaya konulması olmuştur (Sherif vd., 1988: 204).

Sonuç olarak, Sherifin Hırsızlar Mağarası deneyi, gruplararası uyuşmazlığın bir nedeni olarak sınırlı kaynaklar üzerine rekabete dikkat çekmesi itibarıyla önemlidir. Bu deney ve onu destekleyen müteakip çalışmalar, aynı zamanda uyuşmazlık çözümünün etkili bir aracı olarak üst bir hedefin tanınmasına işaret etmektedir. (McKenzie ve Twose, 2015: 313). Buna göre, üst hedeflere ulaşılması için yapılan işbirliği zaman içerisinde gruplararası uyuşmazlığı azaltma ve işbirliği yapan grupların üyeleri arasında olumlu ilişkiler yaratma potansiyeline sahiptir. (Schofield, 2010: 683)

\section{1915 Olayları'na Dair Uyuşmazlığın Nedenlerinin Kuramsal Analizi}

Çalışmanın kuramsal temelinin açıklanmasını takip eden bu bölüm, 1915 Olayları'na dair Türk-Ermeni uyuşmazlığının nedenlerinin, ortaya konulan kuramsal çerçeveden analizine ayrılmıştır. Hâlihazırda bahsedildiği üzere, gerçekçi çatışma kuramına göre gruplararası çatışmanın temelinde, birbiriyle bağdaşmayan grup çıkarları ve hedefleri yatmaktadır. Buna göre, söz konusu Türk-Ermeni uyuşmazlığı da Türkiye ve Ermenistan'ın 1915 Olayları'nın soykırım olarak tanınması/tanınmaması noktasında farklı ve birbiriyle örtüşmeyen çıkarlara sahip olmasından ileri gelmektedir. Tarafların çatışan çıkarlarının anlaşılabilmesi açısından Türkiye ve Ermenistan açısından olayların nasıl anlaşıldığının ve anlatıldığının ortaya konulması gereklidir. Bu gereklilikten yola çıkarak hazırlanan bu bölümde, iki tarafın resmi tezlerini göstermesi açısından, temel kaynak olarak Ermenistan ve Türkiye Dışişleri Bakanlıklarının resmi sitelerinden faydalanılmaktadır. Sırasıyla Ermenistan ve Türkiye Dışişleri Bakanlıklarının 1915 Olayları ve buna bağlı Türk-Ermeni uyuşmazlığını nasıl ele aldıkları incelenmekte ve bu incelemeden elde edilen veriler gerçekçi çatışma kuramı açısından yorumlanmaktadır.

\subsection{Ermenistan'ın Gözünden 1915 Olayları}

Ermenistan'ın gözünden 1915 Olayları'na bakıldığında, Ermenistan'ın Olayları soykırım olarak adlandırdığı ve tüm dünyaya da bu şekilde tanıtmaya çabaladığı görülmektedir. Bu çabanın bir göstergesi olarak Ermenistan Cumhuriyeti Dışişleri Bakanlığı'nın resmi internet sitesinde 1915 Olayları'na ayrı bir bölüm ayrılmıştır. "Soykırımın Tanınması" başlıklı bu bölümde "Soykırım", "Tanınma" ve "Kültürel Soykırım" başlıklı üç alt bölüm bulunmaktadır. "Soykırım" başlığı altında ilk olarak Birleşmiş Milletler (BM)'in soykırım tanımına yer verilmekte, takip eden kısımlarda ise (sözde) Ermeni soykırımının ne olduğu; neden gerçekleştiği; kaç kişinin öldüğü ve (sözde) soykırımın nasıl uygulandığ 1 Ermenistan'ın bakış açısından anlatılmaktadır.

Ermenistan'ın resmi tezine göre, Birinci Dünya Savaşı sırasında Osmanlı İmparatorluğu'nun Ermeni tebaasına karşı gerçekleştirilen "zulüm" Ermeni soykırımı olarak adlandırılmaktadır. Ermenistan'a göre bu "kıyımlar" Osmanlı İmparatorluğu'nun farkl1 bölgelerinde, o dönemde iktidarda bulunan Jön Türkler tarafından gerçekleştirilmiştir. Savaş patlak verdiğinde, zayıflayan imparatorluğun kalan kısımlarını kurtarma ümidinde olan Jön Türkler, PanTürkizm politikasını benimsemiştir. Ermenistan'ın tanımına göre bu politika, İmparatorluğun tüm 
etnik azınlıklarının Türkleştirilmesini de kapsamaktaydı ve Ermeni nüfusu, bu politikanın gerçekleşmesi yolunda temel bir engel haline gelmişti. Bu bağlamda Ermenilerin "Batı Ermenistan"dan (Doğu Anadolu'dan) sürülmesi kararı 1911 yılında alınmış; Jön Türkler Birinci Dünya Savaşı'nı bu kararı uygulamak için uygun bir firsat olarak kullanmıştır.

Yine Ermenistan'ın resmi tezine göre Birinci Dünya Savaşı'ıın arifesinde, Osmanlı İmparatorluğu'nda yaşayan tahmini iki milyon Ermeni ölmüştür. Aynı iddialara göre 1915 ve 1923 yılları arasında yaklaşım 1,5 milyon Ermeni helak olmuş; bir milyon Ermeni ise ya yurtdışına sığınmış ya da Müslümanlaşmıştır.

(Sözde) Soykırımın nasıl uygulandığını anlatan "Uygulama Mekanizması" kısmına gelindiğinde Ermenistan'ın soykırımın, merkezi bir planlama, örgütlü olarak öldürme ve uygulama için bir iç mekanizmanın varlığını içerdiğine vurgu yaptığı ve 1915 Olayları'nın bu vurgulanan hususlarla örtüştüğünü ispat etme kaygısı göze çarpmaktadır. Buna göre, soykırım olarak nitelendirilen olaylar dört aşamada gerçekleşmiştir. Birinci aşamada, 24 Nisan 1915'te, neredeyse yüzlerce entelektüel tutuklanmış ve öldürülmüştür. İkinci aşamada 60,000 Ermeni erkeği, Türk ordusunda mecburi askerlik görevine çağrılmış ve daha sonra silahları alınarak öldürülmüştür. Üçüncü aşama, çocuk, yaşlı ve kadınların kıyımı, sürgünü ve Suriye çöllerine doğru ölüm yürüyüşlerinden oluşmaktadır. Son aşama ise, Türk hükümetinin, Ermeni ulusunun anavatanından tasfiyesini ve kitlesel ölümlerini tamamen ve kesin bir şekilde inkâr etmesiyle tanımlanmaktadır (Ministry of Foreign Affairs of the Republic of Armenia, 2019). "Tanınma" başlıklı bölümde ise 1915 Olayları'nı soykırım olarak kabul eden devletler, örgütler, ilçe yönetimleri ve belediye meclislerinin bir listesi bulunmaktadır.

Ermenistan Dışişleri Bakanlığı'nın resmi sitesinden alınan bu verileri toparlanıp değerlendirildiğinde iki nokta ön plana çıkmaktadır. Birincisi, Ermenistan açısından 1915 Olayları, Osmanlı Devleti'nin Ermeni tebaasına karşı gerçekleştirilmiş örgütlü, planlı ve belirli bir iç mekanizma takip edilerek uygulanmış bir yok etme girişimi; iki milyon Ermeni'nin öldüğü bir soykırımdır. Söz konusu verilerin analizinde dikkat çeken ikinci husus, Ermenistan'ın, Türkiye sınırları dâhilindeki Doğu Anadolu coğrafyasını resmi olarak "Batı Ermenistan" ş̧eklinde adlandırdığıdır. Resmi açıklamalarda "Batı Ermenistan" ifadesinin açık bir şekilde Doğu Anadolu yerine kullanıldığı görülmektedir. Bu durum, 1915 Olayları'nın "soykırım" olduğu tezinin kabulünün, beraberinde birtakım toprak taleplerini de gündeme getireceğinin sinyali niteliğindedir. Yine resmi açıklamalarda, Doğu Anadolu kast edilerek "Ermeni ulusunun anavatanı" denilmesi, Ermenistan'ın bu yönde bir talebi olacağı düşüncesini güçlendirmektedir.

\subsection{Türkiye'nin Gözünden 1915 Olayları}

1915 Olayları ve buna bağlı Türk-Ermeni uyuşmazlığı ile ilgili olarak Türkiye'nin resmi tutumunu, Türkiye Cumhuriyeti Dışişleri Bakanlığı'nın sitesinde "Temel Dış Politika Konuları"nın ele alındığı kısımda, "1915 Olayları ve Türk-Ermeni Uyuşmazlığı" başlığı altında okumak mümkündür. Buna göre, Birinci Dünya Savaşı'ndan önce Osmanlı İmparatorluğu'nun çöküşs süreci başlamıştır. Bu süreçte özellikle Balkanlar'da büyük toprak kayıpları yaşanmış; en az 4,5 milyon Osmanlı tebaası Müslüman hayatını kaybetmiş; yaklaşık beş milyon Osmanlı vatandaşı Balkanlar ve Kafkaslar'daki anayurtlarından sürülmüştür. Kısacası, çöküş ve dağılma sürecinde, İmparatorluğu oluşturan bütün topluluklar acılar yaşamışlardır. Türkiye açısından, Ermenilerin yaşadıkları acılar da bu çalkantılı dönemde İmparatorluğun ortak kaderinin bir parçasıdır.

Türkiye Cumhuriyeti Dışişleri Bakanlığı'nın verilerine göre, 1850 yılından itibaren Ermenilerden 29 kişiye Paşalık unvanı verilmiş; Ermeniler hükümet üyeliği, Meclis-i Mebusan üyeliği, büyükelçilik ve başkonsolosluk görevlerinde bulunmuş; bunlara ek olarak da çeşitli stratejik birimlerin başlarına getirilmişlerdir. Ancak kendilerine tanınan bu olanaklara rağmen bazı Ermeni örgütleri, XIX. yüzyılın ikinci yarısından itibaren, Çarlık Rusyası'nın Osmanlı İmparatorluğu'nu parçalama yönelik politikalarına ve fikirlerine destek vermiştir. $\mathrm{Bu}$ örgütler, 
ayrılıkçı isyanlar çıkarmış; çoğunluğu Müslümanlardan oluşan bölgelerde silahlı saldırılarda bulunmuş ve Birinci Dünya Savaş1 patlak verdiğinde de etnik açıdan homojen bir Ermenistan kurulması için Rus ordusunun saflarında Osmanlı Devleti'ne karşı savaşmıştır.

Özellikle 15 Nisan 1915'te Van'daki ikinci isyanın ardından Osmanlı Hükümeti, savaş bölgesi ve civarındaki stratejik bölgelerde ikamet eden Ermeni nüfusun, Rus ordusunun ikmal ve ulaşım hatlarından uzaklaştırılması kararı almıştır. Bu karar binaen de söz konusu Ermeni nüfus, İmparatorluğun güney vilayetlerine sevk edilmiştir. $\mathrm{Bu}$ yer değiştirme sırasında Osmanlı Hükümeti'nin, Ermenilerin korunmaları ve beslenmeleri konusundaki tüm tedbirlerine rağmen savaş koşulları, eşkıyalık, açlık, salgın hastalıklar ve dağılmakta olan imparatorluktaki genel hukuksuzluk durumu nedeniyle büyük acılar yaşanmıştır. Emirlere karşı gelerek Ermeni konvoylarına karşı suç işleyen ve böylelikle acıların yaşanmasında payı olan bazı Osmanlı devlet görevlileri ise idam da dâhil olmak üzere çeşitli cezalara çarptırılmıştır.

Türkiye'ye göre Ermenistan bu olayları "soykırım" olarak tanımlayarak tek doğru politik yaklaşım olarak dayatmakta ve buna karşı bir tutumu ise "inkârcılık" olarak etiketlemektedir. Oysa Türkiye açısından "soykırım" lafzı yalnızca bir iddiadır ve doğası gereği bir iddia "inkâr" edilemez, sadece sorgulanabilir. Ermenistan, karşıt söylemi nedeniyle tartışmayı engellemek adına bilinçli olarak "inkâr" ifadesini kullanmaktadır.

1915 Olayları'nın uluslararası toplumun bir kesimi tarafindan soykırım olarak tanınması noktasında ise Türk Dışişleri Bakanlığı, söz konusu tanıma kararlarının yalnızca günlük siyasi iradeyi yansıttığını ve hukuki bağlayıcılık taşımadığını vurgulamaktadır. Bu noktada Türkiye, 1915 Olaylarını soykırım olarak nitelendiren herhangi bir uluslararası ceza mahkemesi kararının bulunmadığına da dikkat çekmektedir.

Nihayetinde Türkiye, "adil bir hafıza" çağrısı yapmaktadır. Bunun gerçekleşmesi için de kendi arşivleri ile Ermenistan ve üçüncü ülkelerdeki arşivlerde 1915 Olayları konusunda araştırılması yapılması için uluslararası bir ortak tarih komisyonunun oluşturulmasını önermektedir. Ancak Türkiye'nin gözünde Ermenistan, bu ve buna benzer adımlara karşl1ık vermemektedir (Türkiye Cumhuriyeti Dışişleri Bakanlığı, 2019).

\subsection{Türkiye ve Ermenistan'ın Çatışan Hedefleri}

Tüm bu veriler 1şı̆̆ında değerlendirildiğinde, Ermenistan'ın, 1915 Olayları'nın Türkiye tarafından soykırım olarak tanınmasını sağlayarak bir yandan prestij kazanırken diğer yandan da Ermenistan'ın toprak taleplerinin meşru zeminini oluşturmay1 hedeflediğini düşünmek yanlış olmayacaktır. Ermenistan bu hedefine ulaştı̆̆ 1 takdirde ise Türkiye, işlemediği bir suçu kabul ederek prestij kaybedecek ve bu kabulün beraberinde gelmesi muhtemel toprak taleplerini göğüslemek durumunda kalacaktır.

Dolayısıyla, 1915 Olayları'na bağlı olarak yaşanan uyuşmazlığın temelinde, olayların nasıl tanımlanması gerektiği noktasında Türkiye ve Ermenistan'ın farklı çıkarlarının ve hedeflerinin olması yatmaktadır. Gerçekçi çatışma kuramının argümanlarına paralel olarak, bu durumda gruplardan birisinin hedefine ulaşmakta başarılı olması, diğer grubun başarısızlığ 1 anlamına gelmektedir. Bu tür bir uyuşmazlığın yansıması olarak da Türk ve Ermeni toplumları, birbirlerine karşı olumsuz tepkileri besleyen önyargılar, kalıpyargılar ve iç-grup normları geliştirebilmekte ve bunlar, iki grup arasındaki karşılıklı davranışları belirlemektedir.

\section{Uyuşmazlığın Çözülmesine Yönelik Geçmiş ve Mevcut Sivil Toplum Girişimleri}

1915 Olayları'na dair uyuşmazlığın çözülmesi ve Türk-Ermeni ilişkilerinin geliştirilmesi adına 1990'lı yıllardan itibaren çeşitli sivil toplum girişimleri gerçekleştirilmiştir. Bu girişimlerden bazıları amacına ulaşamadan nihayete ermiştir; bazıları ise hâlihazırda devam etmektedir. Çalışmanın bu kısmında, bu konuda ön plana çıkan başlıca sivil toplum faaliyetleri incelenmekte ve bunların neden başarısız olduğu ya da henüz başarıyla sonlanmadığı gerçekçi çatışma kuramı 
perspektifinden analiz edilmektedir. Zira bu tür bir analiz sonucunda tespit edilen eksiklik, aksaklik ya da sorunlar, bundan sonra gerçekleşecek girişimler için bir nebze de olsa katkı sağlama potansiyeline sahiptir.

\subsection{Türk-Ermeni Uzlaştırma Komisyonu}

Türk-Ermeni Uzlaştırma Komisyonu/Turkish-Armenian Reconciliation Commission (TARC), iki ülke arasındaki ilişkilerin geliştirilmesi amacıyla, sivil aktörler tarafından iki ülke hükümetlerinin de bilgisi dâhilinde oluşturulmuştur. Amerika Birleşik Devletleri (ABD) Dışişleri Bakanlığı'nın desteğini de alan girişim, 9 Temmuz 2001 tarihinde kamuoyunun bilgisine sunulmuştur. Komisyon, kuruluş aşamasında dördü Türkiye'den ve altısı Ermenistan'dan olmak üzere on temsilciden oluşmuştur (Görgülü, 2008: 19). Komisyonun oluşturulmasından kısa bir süre sonra soykırım tartışmaları, çalışma gündeminin bir numaralı maddesi haline gelmiştir (Phillips, 20.04.2005).

Komisyon'da 1915 Olayları tartış1lırken iki tarafın da resmi tezlerin ödün vermemesi üzerine taraflar, XX. yüzyılın başında yaşanmış olaylara Soykırım Sözleşmesi'nin uygulanabilirliği konusunda hukuki açıdan bağlayıcı olmayan için saygın bir sivil toplum kuruluşu olarak bilinen Geçiş Hukuku Uluslararası Merkezi/International Center for Transational Justice (ICT), konu hakkındaki görüşünü bir rapor olarak yayınlamıştır. Ancak ne Türkiye ne de Ermenistan açıklanan rapordan hoşnut olmamıştır. Zira rapor bir yandan Soykırım Sözleşmesi'nin geriye yürütülemeyeceğini ve dolayısıyla herhangi bir devletten hukuki, finansal ya da toprak ile ilgili hak talep edilemeyeceğini açılarken diğer yandan ise 1915 Olaylarının belirli bir gruba yönelik eylemlerin bir parçası olması ve en azından bazı Osmanlı yöneticilerinin, Ermenilerin yer değiştirmesi kararının çok sayıda ölümle sonuçlanacağını bilmesi nedeniyle bu olayların, soykırımsal bir niyet taşıdığını yazmıştır (Phillips, 20.04.2005). Birinci açıklama Ermeni tarafında hoşnutsuzluk yaratırken ikinci açıklama ise Türk tarafı açısından kabul edilemez bulunmuştur. Başta Emekli Büyükelçi Gündüz Aktan olmak üzere bazı Türk üyeler Komisyon'dan istifa etmiştir. İstifa edenlerin yerine yeni üyeler atanmış, ancak Komisyon derin görüş ayrılıkları dolayısıyla çalışamaz duruma gelmiş̧ir (Lütem, 2015: 245).

ICT raporunun yarattığı hoşnutsuzluğun yanı sıra Ermenistan içinden gelen tepkilerin de Komisyon'un başarısını sekteye uğratan bir unsur olduğu anlaşılmaktadır. Başta Taşnak Partisi olmak üzere Ermeni toplumunun bazı kesimleri tarafindan, uzlaşıyı amaçlayarak (sözde) soykırımın uluslararası kabulünü tehlikeye düşürdügü gerekçesiyle eleştirilmiştir (Görgülü, 2008: 21). Komisyon'un kolaylaştırıcılık görevini yürüten Amerikalı diplomat David Philips de birçok Ermeni'nin başta Komisyon'a onay verdiğini, ancak sonlara doğru geri adım attığını ifade etmiştir. Nitekim Komisyon'un tüm Ermeni üyeleri, Dışişleri Bakanlığı'nın bilgisi dâhilinde hareket ettiklerini söylerken Dışişleri Bakanlığı, 13 Temmuz 2001 tarihinde "Bakanlığın uzlaşma komisyonu ile hiçbir ilgisi yoktur" şeklinde bir açıklama yapmıştır. Komisyon'daki Türk temsilcilerden olan Gündüz Aktan da Ermeni temsilcilerden Van Krikorian'ın Komisyon'a girdiği için ölümle tehdit edildiğini, hatta ailesini başka bir yere taşımak zorunda kaldığını ve bu yüzden çok ciddi bir hastalık geçirdiğini anlatmaktadır (Ersoy, 12.03.2005). Nihayetinde Türk-Ermeni Uzlaşma Komisyonu, 14 Nisan 2004 tarihinde dağılmıştır.

\subsection{Viyana Türk-Ermeni Forumu}

2003 yılında Türk tarihçi Dr. İnanç Atılgan, Ermeni tarihçi Artem Ohandjanian ve Viyana Üniversitesi Tarih Profesörü Wolf Dieter Bihl ve Kerstin Tomenendal ile birlikte Viyana TürkErmeni Platformu (VAT) adında bir platform kurmuştur. 2004 yılının sonlarında ise bu platform, Türk ve Ermeni tarihçilerin 1915 Olaylarını tartışmak üzere masaya oturacağı bir buluşma organize etmiştir. Buna göre, Türk ve Ermeni tarafları 1915 Olaylarına ilişkin ellerinde bulunan belgelerin belirli bir tarihe kadar olanlarını VAT'a iletecek ve ellerindeki belgeleri birbiriyle takas edecekti. 
Kapalı oturum şeklinde gerçekleştirilecek buluşmanın ardından ise sunulan belgeler kitap haline getirilecekti (Usul, 07.02.2004).

Karşılıklı suçlamalar olmadan, tarihçi gözüyle olayları tartışmayı hedefleyen VAT toplantılarının ilki Temmuz 2004'te Viyana'da yapılmıştır. Ancak Mayıs 2005'te gerçekleşmesi beklenen ikinci toplant, Ermeni tarihçilerin vaat ettikleri belgeleri Platform'a göndermemeleri üzerine iptal edilmiştir. VAT, yazılı açıklamasında şöyle demiştir:

"Bu, geçen 90 yıl içerisinde Türk ile Ermeni bilim adamlarının tarafsız bir platformda bilimsel olarak en yakın teması olmuştur. Bunu başaran VAT, bu ilk girişiminin planlanan zaman zarfinda gerçekleşmemesini büyük bir üzüntüyle karşılamasına rağmen, önümüzdeki yıllarda tarihi olaylara müdahil her tarafin kendi tarihiyle yüzleşmesi kapsamında platform olarak hizmet vermeye devam edeceğini bildirir" (Türk-Ermeni Tarihçiler Toplantısı İptal, NTVMSNBC, 12.01.2005).

Ancak bu açıklama, bir temenninin ötesine geçememiştir.

\subsection{Türk-Ermeni İş Geliştirme Konseyi}

Türk-Ermeni İş Geliştirme Konseyi/Turkish-Armenian Business Development Council (TABDC) 3 Mayıs 1997 tarihinde İstanbul ve Erivan'da eş zamanlı kurulmuştur. Böyle bir konseyin kurulması fikri, aynı yıl İstanbul'da düzenlenen Karadeniz Ekonomik İşbirliği Teşkilatı zirvesinde, Türkiye ve Ermenistan arasında ekonomik ilişkilerin kurumsallaştırılması konusu görüşülürken gündeme gelmiştir (Görgülü, 2008: 21). Konsey, iki ülkenin toplumlarının kamu ve özel sektörlerinin arasındaki ilk ve tek resmi bağ olma özelliğine sahiptir. Konsey'in amacı, Türk ve Ermeni iş çevreleri arasında yakın işbirliğini geliştirmek ve iki ülkenin şirketlerinin faaliyetlerini ve iletişimlerini kolaylaştırmaktır. Konsey kendisini, yakın işbirliğinin teşvik edilmesinde bir aracı olarak konumlandırmaktadır. Bu amaca ve konumlandırmaya uygun olarak TABDC, TABDC, ortak kültürel varlıkların korunması adına Van'da bulunan Akdamar Kilisesi'nin restorasyonu konusunda ilk teması gerçekleştirmiştir. Yine Türkiye ve Ermenistan'daki üniversiteler arasındaki ilk temas olarak TABDC'nin girişimiyle Orta Doğu Teknik Üniversitesi (ODTÜ) ve Erivan Devlet Üniversitesi arasında öğrenci değişimine ilişkin bir protokol imzalanmıştır. 1999 yılında Türk ve Ermeni müzisyenlerin katılımıla iki ülkenin müzisyenleri arasında bir ortak müzik albümünün hazırlanması süreci koordine edilmiştir. Türkiye-Ermenistan arasında sınır ötesi ticaretin geliştirilmesi için bir adım olarak Sanal Tarımsal Toptan Market düzenlenmiştir. 2001 yılında Ankara Yaylı Sazlar Dörtlüsü Erivan'da; ertesi yıl ise Komitas Dörtlüsü İstanbul'da bir konser düzenlemiştir (TABDC, 2019).

Kısacası, TABDC kuruluşundan itibaren Türkiye ve Ermenistan arasında iş gezileri düzenlemekte, iki ülke arasında kültürel ve akademik değişim programları yürütmekte, TürkErmeni sınırının açılması konusunda lobicilik faaliyetleri gerçekleştirmekte, sınır ötesi ilişkileri ve siyasi ilişkilerin normalleşmesini desteklemekte ve bölgesel iş konferansları tertip etmektedir (TABDC, 2019).

\subsection{Türk-Ermeni Barış Girişimi Projesi}

2012 yılında Koç Üniversitesi bünyesinde sosyal etki odaklı araştırma ve uygulama merkezi olarak kurulan Koç Üniversitesi Sosyal Etki Forumu/Koç University Social Influence Forum (KUSIF) (KUSIF, 2019), bu işlevleri çerçevesinde, Türk-Ermeni ilişkileri konusundaki sorunlara çözümler üretmek amaciyla Türk-Ermeni Barış Girişimi Projesi'ni ortaya koymuştur. İki ulus içindeki gençlerde Türk-Ermeni uyuşmazlığı hakkında farkındalık yaratmayı öngören proje kapsamında, Türkiye ve Ermenistan'dan genç akademisyenlerin ve sivil toplumun, iki toplumun barışına yönelik görüşlerini paylaştıkları ve sonuncusu 2014'te gerçekleşen YoungTalks adlı etkinlikler serisinin düzenlenmesi; Türkiye-Ermenistan ilişkileri üzerinde çalışan sivil toplum kuruluşlarıyla yapılan söyleşilerden oluşan "Barış Bizim Elimizde Söyleşi Kitapçı̆̆ı"nın 
yayınlanması ve iki ülkenin ilişkileri konusunda gençlerin barışın inşasına yönelik fikirleri arasında yapılan "Barış ve İnsan Hakları Yarışması"nın düzenlenmesi gibi çalışma ve faaliyetler gerçekleştirmiştir (KUSIF, 2019).

\subsection{Avrasya İncelemeleri Merkezi}

2009 yılında kurulan Avrasya İncelemeleri Merkezi (AVIMM)'nin amacı, Türkiye için stratejik öneme sahip olan bölgelerdeki güncel siyasi gelişmeleri analiz etmek ve yorumlamaktır. Türkiye'nin jeopolitik konumu dolayısıyla Kafkasya'ya büyük önem gösterilmesi gerektiğine inanan AVIM, bu çerçevede, ihtilaflı Türk-Ermeni ilişkilerine özel bir önem atfetmektedir. 1915 Olaylarına ilişkin tarihi belgeleri içeren yayınlar; Türk-Ermeni uyuşmazlığı ve Türkiye-Ermenistan ilişkilerinin geleceği konularında düzenlenen kongreler ve sempozyumlar; Ermeni Araştırmaları başlıklı akademik hakemli derginin yayınlanması AVİM'in bu bağlamda hayata geçirdiği faaliyetlerin örneklerindendir (AVIM, 2019).

\subsection{Türkiye Ekonomik ve Sosyal Etüdler Vakfı}

1994 yılında kurulan Türkiye Ekonomik ve Sosyal Etüdler Vakfı (TESEV), başlangıçta yoksulluk, ekonomi, sektör politikaları gibi konularla ilgilenirken 2004 yılından itibaren faaliyet alanları arasına dış politikayı da eklemiştir (TESEV, 2019). TESEV'in ilgilendiği dış politika konularından birisi Türkiye'nin ikili ilişkileri olmakla birlikte ikili ilişkiler konusundaki yayın ve etkinliklerde Türkiye-Ermenistan ilişkilerinin önemli bir yer tuttuğu görülmektedir.

TESEV, Aralık 2006'da Ermenistan'a bir ziyaret gerçekleştirerek Ermenistan'daki benzer kurumlarla, Ermeni gazetecilerle ve sivil toplum kuruluşlarıyla görüşmeler gerçekleştirilmiştir. Ermenistan'daki çeşitli kurumlarla bağlantılar ve ortaklıklar kuran TESEV, bu kurumlarla birlikte raporlar yayınlamakta, konferans ve toplantılar düzenlemektedir (Barış Bizim Elimizde Söyleşi Kitabı, 2014: 12-13). Bunun yanı sıra TESEV, Türklerin ve Ermenilerin karşılıklı algıları üzerine anket çalışmaları gerçekleştirmektedir. Ermenistan ve Türkiye Vatandaşları Karşılıklı Algılama ve Diyalog Projesi, bu çalışmaların ön plana çıkan ve önemli bir örneğidir.

\subsection{Türkiye Ekonomi Politikaları Araştırma Vakfı}

Türkiye Ekonomi Politikaları Araştırma Vakfı (TEPAV), 2004 yılında veriye dayalı politika analizi yapmak ve politika yapımı sürecine katkıda bulunmak üzere bir grup iş insanı, bürokrat ve akademisyen tarafindan kurulmuştur. Ekonomi, yönetişim ve diş politika olmak üzere üç çalışma alanı bulunan TEPAV, bu kapsamda Türkiye-Ermenistan ilişkileri ile de ilgilenmektedir. Türkiye-Ermenistan Girişimcilik Programı, Türkiye-Ermenistan Normalleşme Süreci Destek Programı'na katkı, Türk ve Ermeni girişimcilere ortak eğitimler verilmesi, Türkiye ve Ermenistan arasında Girişimciler Destek Programı'nın düzenlenmesi ve iki ülkenin ilişkilerine dair raporlar hazırlanması, TEPAV'ın Türkiye-Ermenistan ilişkileri konusundaki çalışmalarının ve faaliyetlerinin örneklerindendir (TEPAV, 2019).

\subsection{Hrant Dink Vakfı}

Agos gazetesinin yayın yönetmeni olan Ermeni asıllı gazeteci Hrant Dink'in 19 Ocak 2007 tarihinde öldürülmesinin ardından kurulan Hrant Dink Vakfi, tüm faaliyetlerinin temeli olarak diyalog, barış ve empati kültürünü geliştirmeyi tanımlamaktadır. Bu temele dayan vakıf, Türkiye ve Ermenistan toplumları arasındaki kültürel ilişkilerin geliştirilmesi konusunda da çalışmalar yürütmektedir. Vakfin bünyesinde Türkiye-Ermenistan Programı kapsamında Türkiye-Ermenistan Seyahat Fonu, Burs Program1, Gazeteci Diyalog Program1, Uzmanlar Diyalog Grubu gibi faaliyetler gerçekleştirilmektedir (Hrant Dink Vakfı, 2019).

\section{Geçmiş ve Mevcut Girişimlerin Kuramsal Açıdan Değerlendirilmesi}

Çalışmanın buraya kadar olan kısmında hem nihayete eren sivil toplum girişimleri hem de hâlihazırda aktif şekilde faaliyet gösteren sivil toplum kuruluşlarının ajandalarının bir parçası 
olarak süren çalışmalara ve faaliyetler ele alınmıştır. Bunlardan bazıları doğrudan 1915 Olayları'na odaklanırken bazıları ise daha genel anlamda Türk-Ermeni ilişkilerini konu etmektedir. Ancak Türk-Ermeni ilişkileri söz konusu olduğunda da 1915 Olayları'nın temel bir gündem maddesi haline gelmesi şüphesiz ki kaçınılmazdır. Dolayısıyla, burada ele alınan tüm girişimler, faaliyetler ve çalışmalar bir şekilde 1915 Olayları'na dair uyuşmazlığa temas etmektedir.

Buraya kadar yer verilen bilgiler, başarısızlıkla sonuçlanan ve kendi çapında başarısız olmamakla birlikte 1915 Olayları'na dair uyuşmazlığa nihai bir çözüm getirememiş olan sivil toplum girişimleri ile ilgili birtakım sonuçlara varmayı mümkün kılmaktadır. Çalışmanın bu bölümünde bu sonuçlar, gerçekçi çatışma kuramı açısından ortaya konulacaktır.

Gerçekçi çatışma kuramı, birbiriyle çatışan hedeflerin ve çıkarların varlığından kaynaklanan gruplararası uyuşmazlıkların çözülmesi için birtakım üst hedeflerin belirlenmesini önermektedir. Bunlar, her iki grup için de çekiciliği yüksek olan; iki grup tarafından da göz ard1 edilemeyecek, ancak ulaşılmasının yalnızca bir grubun kaynakları ve çabalarının ötesinde olduğu hedeflerdir (Sherif vd., 1988: 204). Bu tür hedeflerin konulmasındaki amaç, karşıt grupların üyeleri arasında sosyal temas sağlayarak onları yakınlaştırmaktır.

Geçmiş ve mevcut sivil toplum girişimleri düşünüldüğünde, bu çalışmada incelenen faaliyetlerin bazılarında Sherif'in tanımladığı türde üst hedeflerin varlığ 1 söz konusuyken bazılarında ise bu tür hedeflerin varlı̆g 1 görülmemektedir. Örneğin, TARC bünyesinde gerçekleşen çalışmalarda üst hedeflerin varlığına rastlanmamaktadır. Özellikle 1915 Olayları tartış1ırken doğrudan olayların soykırım olup olmadığına dair bir sonuca varılmasına odaklanılmışıtır. Benzer şekilde, VAT tarafindan 1915 Olayları'nı tartışmak üzere düzenlenen toplantılarda doğrudan olayların nasıl tanımlanacağını belirlemek üzere resmi belgelerin incelenmesi ile ilgilenilmiştir. Tarafların ulaşmak için birlikte çabalamak zorunda olduğu üst hedefler ortaya konulmaksızın direkt 1915 Olayları'nın tanımlanmasına odaklanan bu girişimlerde, doğal olarak, başarılı sosyal temasın bir diğer unsuru olan gruplar arasında işbirliği de gerçekleşmemiştir. Sonuç olarak ise bu girişimler esnasında gerçekleşen sosyal temas, gruplararası çatışmanın çözülmesi açısından başarısızlıkla sonuçlanmiştır.

Diğer yandan, üst hedeflerin konulduğu sivil toplum girişimlerinde sosyal temasın bir başarısızlık getirmediğinin söylemek mümkündür. Türk ve Ermeni müzisyenlerin ortak bir müzik albümü hazırlamaları; sınır ötesi ticareti ve girişimciliği teşvike yönelik olarak sanal ortamda ortak bir market kurulması ile iki ülkenin girişimcilerine ortak programlar düzenlenmesi; iki ülkenin sanatçılarını bir araya getiren sanatsal ve kültürel etkinlikler bu kapsamdadır. Bu etkinlikler, iki grubun üyelerinin birlikte hareket etmelerini gerektiren etkinlikler oldukları için gruplararası işbirliğini de beraberinde getirmektedir. Taraflar, doğrudan 1915 Olayları'na ve buna bağlı uyuşmazlığa değinmeksizin kültürel, sanatsal, eğitimle ilgili, mesleki ya da ticari bir üst hedef bağlamında bir araya gelmektedir. Doğrudan 1915 Olayları'nın tanımlanmasına odaklanan girişimlerle kıyaslandığında, üst hedeflere odaklanarak gruplararası teması sağlamayı hedefleyen girişimlerin, kesin ve kalıcı çözümü getirememiş olsalar da, başarısızlıkla sonuçlanmadığ görülmektedir. Ancak öte yandan söz konusu girişimler, üst hedeflerin ve gruplararası işbirliğinin varlığına rağmen, uyuşmazlığa nihai bir çözüm getirememiştir. Başka bir deyişle, üst hedeflere ulaşmada başarılı olmuşlar, fakat bu başarının gruplararası uyuşmazlığın bütünüe yayılması gerçekleşmemiştir.

Bu durum, gruplararası uyuşmazlıkların çözümünde, gruplararası işbirliğini zorunlu kılacak üst hedeflerin belirlenmesinin gerekli olduğunu, ancak yeterli olmadığını göstermektedir. Buradan hareketle bu çalışmada, gerçekçi çatışma kuramının, çalışmanın kuramsal kısmında bahsedilen Allport'un sosyal temas yaklaşımı ile tamamlanması gerektiği savunulmaktadır. Buna göre, yapılandırılmış deney ortamından farklı olarak uluslararası ilişkiler söz konusu olduğunda, gruplararası temasın, gruplararası çatışmaların çözümünde başarılı olabilmesi için, üst hedeflerin ve buna bağlı olarak ortaya çıkan gruplararası işbirliğinin yanı sıra bu süreci destekleyen üçüncü 
tarafların varlığı bir gerekliliktir. Bu noktada, bu çalışmada incelenen sivil girişimlerin zaman zaman söz konusu desteği görürken zaman zaman ise bundan mahrum kaldığ 1 sonucuna varılmaktadır. Oysaki iki taraf açısından da "kırmızı çizgi" olarak tabir edilebilecek 1915 Olayları gibi bir konuda, sivil toplum girişimlerinin başarılı olması için hükümetlerin desteği bir gerekliliktir.

$\mathrm{Bu}$ gerekliliğin manevi ve maddi olarak adlandırılabilecek ve birbiriyle bağlantılı iki boyutu vardır. Manevi boyut meşruiyet ile ilgilidir. Önceki satırlarda bahsedildiği üzere 1915 Olayları'nın nasıl tanımlandığı Ermenistan açısından olduğu gibi Türkiye Cumhuriyeti Devleti açısından da bir kırmızı çizgi niteliğindedir. Zira soykırımın iddialarının kabulü bir yandan prestij kayb1 bir yandan da ardından gelecek toprak talepleriyle birlikte Türkiye topraklarının bölünmezliğini bütünlüğünü ifade eden mutlak egemenlikten taviz anlamına gelmektedir. $\mathrm{Bu}$ nedenle bu uyuşmazlığın çözümü konusunda atılacak sivil adımların, devletin onayı dâhilinde olması ve devlet politikasına ters düşmemesi, bu girişimlerin başarısı açısından oldukça önemlidir.

$\mathrm{Bu}$ durumun bir göstergesi olarak TABDC Başkan Yardımcısı Noyan Soyak, bir iş geliştirme konseyi kurulması önerisi gündeme geldiğinde gerekli mercilere danıştıklarını, onay aldıklarını ve bir sakınca olmayacağı teyit ettirdiklerini ifade etmektedir (Barış Bizim Elimizde Söyleşi Kitabı, 2014: 7). Soyak'n işaret ettiği "gerekli merciler" şüphesiz ki dönemin hükümetidir. Soyak'ın açıklamalarına ek olarak, TEPAV İcra Direktörü Güven Sak'ın, Türkiye-Ermenistan konusundaki projelerinin gelişme sürecini anlatırken kullandığı şu ifadeler, Ermenistan ile ilgili konulardaki girişimlerde devlet desteğinin önemini göstermektedir: "Zamanla bu konuda konuşmak giderek meşrulaşt1. Ermenistan'la ilgili konularda konuşmak için kahraman olma gerekliliği ortadan kalktı" (Barış Bizim Elimizde Söyleşi Kitabı, 2014: 36). Sak konuşmasının devamında, özellikle dönemin (görüşmenin yapıldığı 21 Haziran 2014 tarihinde) Başbakanı Recep Tayyip Erdoğan'ın açıklamasından sonra Türkiye-Ermenistan ilişkileri konusunda görünmeden iş yapma zorunluluğunun ortadan kalktığını; Türkiye-Ermenistan ilişkilerini iyileştirmek için bir serbestlik alanı oluştuğunu söylemektedir (Barış Bizim Elimizde Söyleşi Kitabı, 2014: 37).

Benzer izlenimleri Ermenistan tarafında da görmek mümkündür. TARC'ın çalışmaları sırasında Ermenistan içinden gelen tepkilerin Komisyon'un başarısını sekteye uğratması bunun bir örneğidir. Hâlihazırda bahsedildiği gibi, başta Taşnak Partisi olmak üzere Ermeni toplumunun bazı kesimleri TARC'1 eleştirmiş; Ermeni temsilcilerden Van Krikorian Komisyon'a girdiği için ölümle tehdit edilmiş, hatta ailesini başka bir yere taşımak zorunda kalmıştır. Şüphesiz ki Ermenistan Dışişleri Bakanlığı'nın, Bakanlık ile uzlaşma komisyonunun ile hiçbir ilgisinin olmadığını açıklaması, Komisyon'un meşruluğuna gölge düşürerek söz konusu olumsuzlukların yaşanmasının önünü açmış ya da bertaraf edilmesini olanaksız hale getirmiştir. Dolayısıyla, 1915 Olayları ve buna bağlı uyuşmazlık gibi hassas bir konuda sivil toplum girişimlerinin başarılı olması için meşru görülmeleri ve bunun için de hükümetler tarafindan desteklenmesi gerekmektedir.

Sivil toplumlar arasındaki ilişkilerde üçüncü taraf olarak hükümetlerin desteğinin bir zorunluluk olmasının maddi boyutu da esasında manevi boyutla yani meşruiyet meselesiyle yakından ilgilidir. Sivil toplum düzeyindeki tüm girişimler, çalışmalar, düzenlenen tüm etkinlikler ve projeler maddi kaynağa yani fona ihtiyaç duymaktadır. TESEV Dış Politika Programı Yöneticisi Aybars Görgülü, Türkiye-Ermenistan ilişsileri konusundaki çalışmalar için fon buldukları ilk dönemin futbol diplomasisi ve protokoller sürecine denk geldiğini belirtmektedir. Görgülü, resmi bir süreç varsa uluslararası aktörlerin bu süreci desteklediğini; ilişkiler tıkanma noktasında geldiğinde ise büyük fonların ve sivil toplum çalışmalarını destekleyenlerin azaldığını vurgulamaktadır (Barış Bizim Elimizde Söyleşi Kitabı, 2014: 14). Görgülü'ye göre, kendi kurumu TESEV de dâhil olmak üzere, Türkiye'de hiçbir sivil toplum örgütü kendi öz kaynaklarını kullanarak Türkiye-Ermenistan ilişkileri üzerine çalışamaz. Dolayısıyla, diplomatik girişimlerin tıkanma noktasına gelip, bu konudaki çalışmalara fon veren pek kalmayınca, projeleri gerçekleştirmek de güçleşmektedir (Barış Bizim Elimizde Söyleşi Kitabı, 2014: 15). 


\section{Sonuç}

Türk dış politikasında bir sorun olarak tanımlanan 1915 Olayları'na bağlı Türk-Ermeni uyuşmazlığ 1 ve sivil toplum girişimlerinin uyuşmazlığın çözümündeki başarısının gerçekçi çatışma kuramı açısından ele alınması, hem uyuşmazlığın temelinde yatan sebeplere hem de uyuşmazlığın çözümünde henüz başarı sağlanamamasına sebep olan eksiklik ve aksaklıklara açıklama getirmektedir. Buna göre, 1915 Olayları'na bağlı olarak yaşanan uyuşmazlığın temelinde, olayların nasıl tanımlanması gerektiği noktasında Türkiye ve Ermenistan'ın farklı çıkarlarının ve hedeflerinin olması yatmaktadır. Tarafların resmi tezlerinin incelenmesi, Ermenistan'ın, 1915 Olayları'nın Türkiye tarafından soykırım olarak tanınmasını sağlayarak bir yandan prestij kazanırken diğer yandan da Ermenistan'ın toprak taleplerinin meşru zeminini oluşturmayı hedeflediğini ortaya koymaktadır. Ermenistan bu hedefine ulaştığı takdirde ise Türkiye, işlemediği bir suçu kabul ederek prestij kaybedecek ve bu kabulün beraberinde gelmesi muhtemel toprak taleplerini göğüslemek durumunda kalacaktır. Dolayısıyla, 1915 Olayları'na bağlı olarak yaşanan uyuşmazlığın temelinde, olayların nasıl tanımlanması gerektiği noktasında iki devletin farklı çıkarlarının ve hedeflerinin olması yatmaktadır. Gerçekçi çatışma kuramının argümanlarına paralel olarak, bu durumda gruplardan birisinin hedefine ulaşmakta başarılı olması, diğer grubun başarısızlığı anlamına gelmektedir. Bu tür bir uyuşmazlığın yansıması olarak da Türk ve Ermeni toplumları, birbirlerine karşı olumsuz tepkileri besleyen önyargılar, kalıpyargılar ve iç-grup normları geliştirebilmekte ve bunlar, iki grup arasındaki karşılıklı davranışları belirlemektedir.

Gerçekçi çatışma kuramı, bu tür uyuşmazlıkların çözümü için, her iki grup için de çekiciliği yüksek olan; iki grup tarafından da göz ardı edilemeyecek, ancak ulaşılmasının yalnızca bir grubun kaynakları ve çabalarının ötesinde olduğu birtakım üst hedeflerin belirlenmesini önermektedir. Bu tür hedeflerin konulmasındaki amaç, karşıt grupların üyeleri arasında sosyal temas sağlayarak onları yakınlaştırmaktır. Geçmiş ve mevcut sivil toplum girişimleri düşünüldügünde, bu çalışmada incelenen faaliyetlerin bazılarında Sherif'in tanımladığı türde üst hedeflerin varlığı söz konusuyken bazılarında ise bu tür hedeflerin varlığı görülmemektedir. Doğrudan 1915 Olayları'nın tanımlanmasına odaklanan girişimlerle kıyaslandığında, üst hedeflere odaklanarak gruplararası teması sağlamayı hedefleyen girişimlerin, kesin ve kalıcı çözümü getirememiş olsalar da, başarısızlıkla sonuçlanmadığı görülmektedir. Ancak öte yandan söz konusu girişimler, üst hedeflere ulaşmada başarılı olmuşlar, fakat bu başarının gruplararası uyuşmazlığın bütünüe yayılması gerçekleşmemiştir.

$\mathrm{Bu}$ durum, gruplararası uyuşmazlıkların çözümünde, gruplararası işbirliğini zorunlu kılacak üst hedeflerin belirlenmesinin gerekli olduğunu, ancak yeterli olmadığını göstermektedir. Buradan hareketle bu çalışmada, gerçekçi çatışma kuramının, çalışmanın kuramsal kısmında bahsedilen Allport'un sosyal temas yaklaşımı ile tamamlanması gerektiği ortaya konulmuştur. Buna göre, yapılandırılmış deney ortamından farklı olarak uluslararası ilişkiler söz konusu olduğunda, gruplararası temasın, gruplararası çatışmaların çözümünde başarılı olabilmesi için, üst hedeflerin ve buna bağlı olarak ortaya çıkan gruplararası işbirliğinin yanı sıra bu süreci destekleyen üçüncü tarafların varlığı bir gerekliliktir. Özellikle 1915 Olayları gibi her iki taraf açısından da "kırmızı çizgi" olarak tabir edilebilecek bir konuda, sivil toplum girişimlerinin başarılı olması için hükümetlerin desteği bir gerekliliktir. Zira bu destek olmaksızın söz konusu girişimlerin meşruiyet ve buna bağlı olarak da fon sağlamakta zorluk çektiği görülmektedir.

Esasında, çeşitli zamanlarda Türkiye ve Ermenistan hükümetleri, gerek 1915 Olayları'na dair uyuşmazlığın çözümü konusunda gerekse genel anlamda Türkiye ile Ermenistan arasındaki siyasi ve diplomatik ilişkilerin tesisi ve geliştirilmesi konusunda siyasi açılımlara imza atmışlardır. $\mathrm{Bu}$ açılımlar belirli bir noktaya kadar gelmiş, ancak çeşitli nedenlerle sonuca ulaşamamıştır. Hükümetler liderliğinde gerçekleşen siyasi açılımların başarısızlıkla sonuçlanması ve buna bağlı olarak iki ülke arasındaki siyasi ilişkilerin tıkanması, sivil toplum girişimlerinin başarısına da gölge düşüren bir unsur olmuştur. Bu nedenle, sivil toplum girişimleri sürekli olarak desteklenmeli; 
zaman zaman gerçekleşen siyasi açlımlardan ziyade açılımlara göre içerik olarak daha az yoğun ama sürekli açık bir süreç olmalıdır.

\section{Kaynakça}

Arkonaç, S. A. (2001). Sosyal psikoloji. İstanbul: Alfa Yayınları.

AVIM. (2019). AVIM hakkında. https://avim.org.tr/tr/Menu/AVIM-Hakkinda. Erişim tarihi. 28.08.2019.

Barış bizim elimizde söyleşi kitabı: Türkiye-Ermenistan toplumları arasında ilişkilerin iyileşmesine dair sohbetler. (2014). (Ed.) Damla Kellecioğlu. İstanbul: Koç Üniversitesi Sosyal Etki Forumu.

Ersoy, P. (12.03.2005). "Ermeniler komisyonu yerden yere vuruyordu (2)." Vatan. http://www.gazetevatan.com/ermeniler-komisyonu-yerden-yere-vuruyordu--2--48965gundem/. Erişim tarihi: 26.11.2019.

Figueiredo, A., Valentim J. P. ve Doosje, B. (2014). "Theories on intergroup relations and emotions: a theoretical overview." Psychologica, 57(2): 7-33.

Görgülü, A. (2008). Türkiye-Ermenistan ilişkileri: bir kssır döngü. İstanbul: TESEV Yayınları.

Gürkaynak, E. Ç. (2018). "Toplumsal temas: önyarg1 ve ayrımcıllğı önlemek için bir sosyal değişim aracı olarak kullanılabilir mi?." Ayrımcılık: çok boyutlu yaklaşımlar. (Ed.) Kenan Çayır ve Müge Ayan Ceyhan. İstanbul: İstanbul Bilgi Üniversitesi Yayınları. 255-265.

Hogg, M. A. ve G. M. Vaughan. (2005). Social psychology. New York : Prentice Hall.

Koç Üniversitesi Sosyal Etki Forumu. (2019). Türk-Ermeni barış girişimi projesi- "barış bizim elimizde". https://kusif.ku.edu.tr/projeler/tamamlanmis-projeler/turk-ermeni-baris-girisimiprojesi-baris-sizin-elinizde/. Erişim tarihi: 28.11.2019.

Koç Üniversitesi Sosyal Etki Forumu. (2019). Hakkımızda. https://kusif.ku.edu.tr/hakkimizda/. Erişim tarihi: 25.11.2019.

LeVine, R. A. ve D. T. Campbell. (1972). Ethnocentrism: theories of conflict, ethnic attitudes, and group behavior. New York: Wiley.

Lütem, Ö. E. (2015). "Türkiye-Ermenistan ilişkilerinin güncel durumu." Ermeni Araştırmaları, 50: 231-373.

McKenzie, J. ve G. Twose (2015). "Applications and extensions of realistic conflict theory: moral development and conflict prevention." Norms, groups, conflict and social change: rediscovering Muzafer Sherif's psychology. (Ed.) Ayfer Dost Gözkan ve Doğa Sönmez Keith. New Brunswick, London: Transaction Publishers. 307-324.

Ministry of Foreign Affairs of the Republic of Armenia. (2019). Genocide. https://www.mfa.am/en/genocide/. Erişim tarihi: 13.11.2019.

Ministry of Foreign Affairs of the Republic of Armenia. (2019). Recognition. https://www.mfa.am/en/recognition/. Erişim tarihi: 13.11.2019.

NTVMSNBC. (12.01.2005). "Türk-Ermeni tarihçiler toplantısı iptal." http://arsiv.ntv.com.tr/news/304933.asp. Erişim tarihi: 26.11.2019.

Pettigrew, T. F. ve L. R. Tropp. (2005). "Allport's intergroup contact hypothesis: its history and influence." On the nature of prejudice: fifty years after Allport. (Ed.) John F. Dovidio, Peter Glick ve Laurie A. Rudman. Malden, Oxford: Blackwell Publishing. 262-277. 
Phillips, D. L. (20.04.2005). "Hopeful signs for Turkey and Armenia." The New York Times. https://www.nytimes.com/2005/04/20/opinion/hopeful-signs-for-turkey-and-armenia.html. Erişim tarihi: 24.11.2019.

Schofiled, J. W. (2010). "Realistic group conflict theory." Encyclopedia of group processes and intergroup relations. (Ed.) John M. Levine ve Michael A. Hogg. Los Angeles: SAGE. 681684.

Sherif, M., O. J. Harvey, B. J. White, W. R. Hood, ve C. W. Sherif. (1988). The robbers cave experiment: intergroup conflict and cooperation. Middletown, Connecticut: Wesleyan University Press.

TABDC. (2019). TABDC-Activities 1997. http://tabdc.org/activity-report/tabdc-activities-1997/. Erişim tarihi: 28.11.2019.

Taylor, D. M. ve F. M. Moghaddam. (1994). Theories of intergroup relations: international social psychological perspectives. Westport, Conn. : Praeger.

TEPAV. (2019). Hakkımızda. https://www.tepav.org.tr/tr/html/250/Hakkimizda/. Erişim tarihi: 28.11.2019.

Türkiye Cumhuriyeti Dışişleri Bakanlığı. (2019). 1915 olaylarına dair Türk-Ermeni uyuşmazlığının arka plan1. http://www.mfa.gov.tr/data/DISPOLITIKA/2016/1915-olaylarina-dairturk_ermeni-uyusmazliginin-tarihi-arka-plani-_turkce.pdf. Erişim tarihi: 12.09.2019.

Usul, S. (07.02.2004). "Ermeni sorununa tarihçiler el koyuyor." Vatan. http://www.gazetevatan.com/ermeni-sorununa-tarihciler-el-koyuyor-22200-gundem/.

Erişim tarihi: 26 Kasım 2019. 